Do mental models influence economic outcomes? Evidence from agricultural policy negotiation in Costa Rica

Elodie Maître d'Hôtel et Tristan Le Cotty

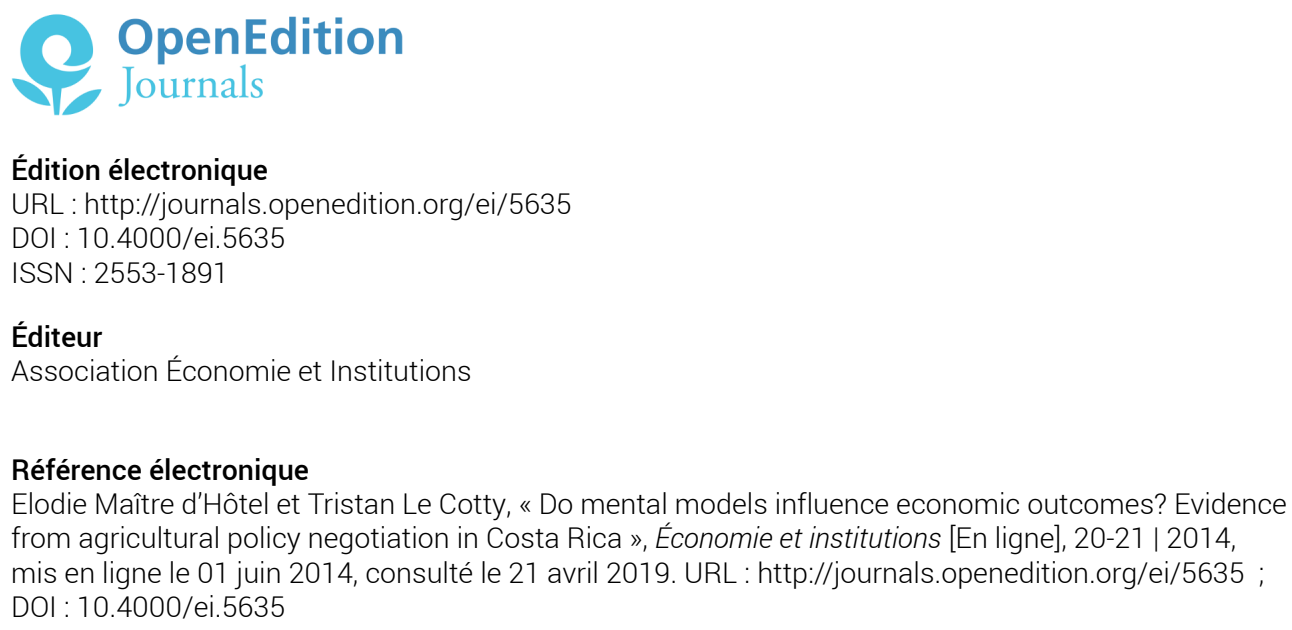

Ce document a été généré automatiquement le 21 avril 2019

Revue Économie et institutions 


\title{
Do mental models influence economic outcomes? Evidence from agricultural policy negotiation in Costa Rica
}

\author{
Elodie Maître d'Hôtel et Tristan Le Cotty
}

\section{Introduction}

1 During a negotiation, some people ask for more than others, and obtain more than others. They do not necessarily have different rights, different bargaining power, or different skills or endowments, but they feel that they deserve a greater outcome than others do. They have a different perception of themselves in the negotiation process, i.e., a different mental model. Thus, they have different expectations of the negotiation, and get a different outcome. And economic theory has a hard time in assessing the role of this on economic outcome. This paper explores the relevance of this idea in the case of a policy negotiation in Costa Rica, and tries to assess the role of mental model in the negotiation outcomes.

2 In Costa Rica, bean and dairy sectors had to face liberalization in 1994 and have taken part to policy negotiations to try and get support from government to compensate for lower prices. Before 1994, both sectors were protected from international markets by a system of high import tariffs. Since that, the dairy sector managed to negotiate a quasi unchanged domestic market protection, while bean sector lost its protection with a drastic reduction of import tariffs. That induced an increase in bean imports from more competitive exporting countries and a decrease in domestic production and many farm went bankrupted. We develop below the argument that this comes partly from their attitude in the negotiation process, and discuss the hypothesis that the bean sector representatives have adopted a "low profile" and defensive attitude because they do not 
see themselves as allowed to claim much from the members of government, and the milk sector representative have adopted a more offensive and proactive attitude because they see themselves as allowed to claim for a large support from the government. Of course, negotiations in these two sectors differ not only by their negotiators attitude, and this is why this article allocate a great effort in distinguishing the very contribution of mental model to the outcome in the bunch of alternative sources of explanation.

the behaviours is not new, but attempts to measure their exact role in economic behaviours are recent and remain somehow theoretical. North coined the term "mental models" to designate representations through which individuals interpret their environment and their relation with this environment, giving rise to a blooming literature on the role of agents' mental models in their economic choices when the latter are not fully understandable through the reading of their economic interest only.

4 Among the many fields where mental models potentially influence decision making, the participation of organizations to policy negotiations is particularly appropriate to our purpose. Indeed, a policy negotiation gathers organizations with different backgrounds in front of a same problem that is basically obtaining as much support from the government as possible. Thus, differences in behaviours reflect what organizations have to gain objectively from this negotiation but also by who they are, what they believe they can gain (see Grindle, 2001). In this paper, we analyze the specific context of trade liberalization in agriculture. Changes brought by liberalization are exogenous to each sector, and the extent to which the government has to compensate for this change is a matter of pure negotiation, without any legal pre-existing framework. The way farmers consider this change as unavoidable or not is critical in the negotiation outcome, and has little to do with the actual welfare loss or even the actual political weight of the farming sector. Mental models prevailing in policy negotiations are "collective" in the sense that leaders' mental models are supposed to be representative of the organization, even though those leaders are probably chosen for their specificities, including their perception and reactivity to institutional changes.

5 To test the hypothesis that mental models influence strategic behaviours, we first give an objective characterisation of each negotiator's mental model. To do so, we propose them a same interview and analyse their speeches through a textual statistical analysis. This analysis does not reveal the content of people's mental model, but simply extracts the words used by each speaker which are statistically characteristics of him. At this stage, the only assumption made is that there is a correlation between the mental model (how the farmer imagines his place in the negotiation) and his language. Then establish a statistical correlation between the negotiation outcome and the four main explanatory factors of this outcome: financial resources, technical resources, human resources and mental models. Our statistical analysis gives credit to the thesis that the fact to have a mental model of a certain type improves the negotiation outcome, in addition to the negotiation ability's effect itself. An important feature to assess this is that language is essentially structural of an individual, it does not change during the life.

6 In section 1, we describe the agricultural policy negotiation problem in Costa Rica. In section 2 we develop how the concept of mental model was introduced in the economic literature and used to explain individual and collective behaviours. In section 3, we present a methodology to give empirical characteristics of a mental model and we apply this method on the negotiators in Costa Rica. In section 4 we present a model of the 
impact of mental model on the negotiation, in section 5 we present the estimation method of this model and in section 6 we present and discuss our results.

\section{The farm policy negotiation problem in Costa Rica}

7 Before liberalization of agriculture in 1994, both bean and dairy sectors were protected from international markets by a mixed system of quotas and high import tariffs, and after 1994, the dairy sector remained protected by high import tariffs while the bean sector had to face a sharp reduction of import tariffs. These differences in policy protection had direct consequences on the evolution of production (Figure 1).

Figure 1. Evolution of bean and milk production in Costa Rica (FAOSTAT data)

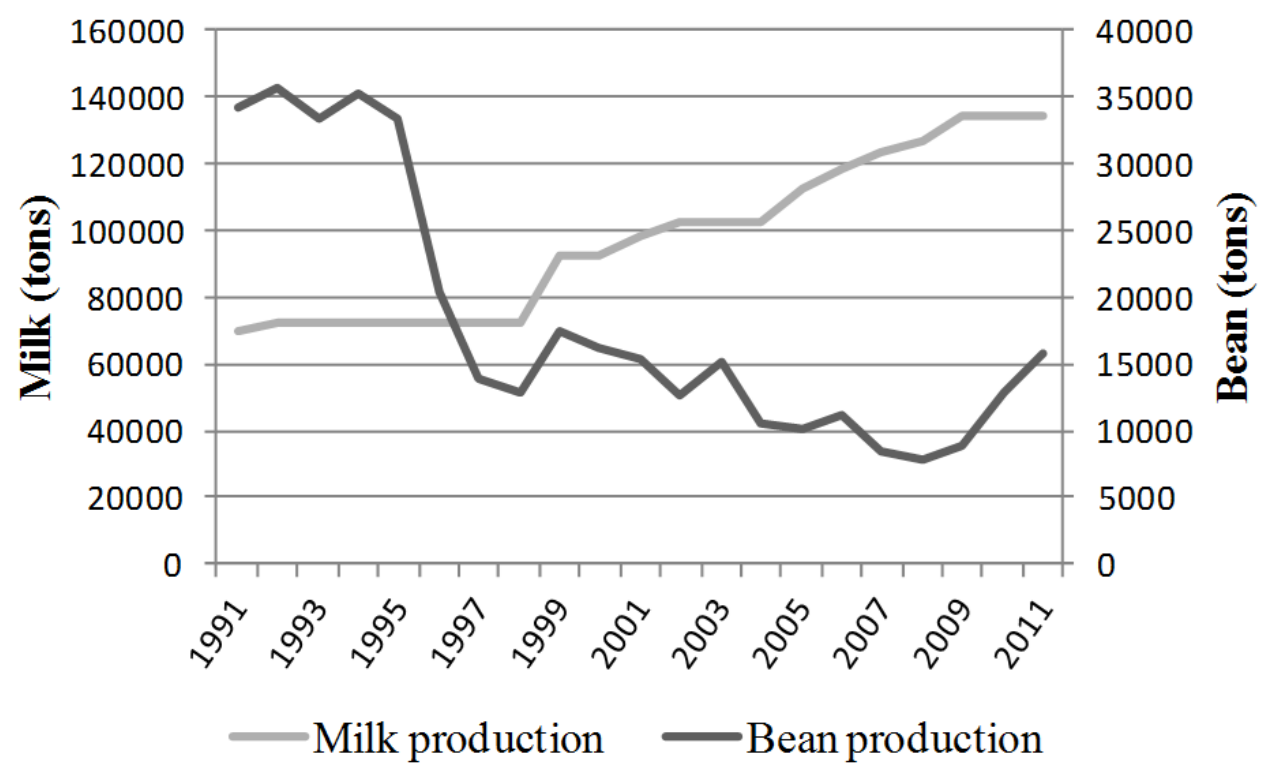

The role of cooperatives in the dairy sector has been crucial since the 1950s in Costa Rica. Milk production is ensured by a limited number of medium-size producers, while transformation and marketing operations are done by cooperatives that represent a market share of $95 \%$. These cooperatives, that emerged in the 1950s, are nowadays quasiintegrated organizations in the sense of Williamson (1996), or Ménard (2007). With more than $80 \%$ of the market share, the Dos Pinos cooperative controls most of domestic market and is developing its activities towards export markets. The dairy sector has been strongly regulated through pricing until 1999 and import-restrictions (importing quotas until 1994, tariffs since 1995). Farmers' organisations have always participated to these policies since 1962, through the activities of advocacy organizations.

In the bean sector, farm organizations emerged in the late 1990s and have not played an active role in policy making processes until recently. Before 1994, the government supported bean production for the sake of consumers, bean being one of the main staple food in Costa Rica, through price subsidies and public agencies ensuring transformation and distribution operations. A large number of small scale farmers benefited from this protectionist policy without having to ask for it since policies were defined by the government without direct participation of bean farmers. 
10 As a consequence of their age and economic power, organizations are globally characterized by a higher resources' endowment in the dairy sector than in the bean sector, in term of financial capacities, technical abilities and policy network insertion.

11 Since Costa Rica adhesion to World Trade Organization in 1994, farmers' main protection action levers are basically import tariffs (import quotas and state market regulation were abandoned). Therefore, although the process and the issues of the negotiation are more complex than this, we focus only on the import tariff, which is the main policy measure with economic consequences in the bean and the dairy sector in Costa Rica. It is common to interpret tariff as a result of political economy (Anderson \& Hayami 1986; Rodrik 1996). As shown in table 2, the negotiated import tariffs for milk and bean are very different. Very high import tariffs in the dairy sector ensures high domestic prices, prevent competing imports, and is a clear economic support (economic transfer from the consumer to the producer). As can be seen in table 1, farmers organizations in the bean sector failed to get tariff protection in 1995 (full market opening meaning loss of domestic market protection), but managed later, in 2003, to negotiate a higher import tariff (domestic market protection during domestic production period).

Table 1. Evolution of negotiated tariffs of milk and bean

\begin{tabular}{|l|l|l|l|l|}
\hline & \multicolumn{2}{l|}{ Milk } & \multicolumn{2}{l|}{ Bean } \\
\hline & 1995 & 2005 & 1995 & 2005 \\
\hline Domestic price (USD/ton) & 255 & 269 & 594 & 570 \\
\hline International price (USD/ton) & 255 & 247 & 430 & 465 \\
\hline Price differential & $12 \%$ & $8 \%$ & $28 \%$ & $18 \%$ \\
\hline Negotiated tariff & $117 \%$ & $93 \%$ & $1 \%$ & Between 0 and 38\% \\
\hline Domestic market protection & Total & Total & None & Modular \\
\hline
\end{tabular}

\section{Some insights from the literature on mental models}

12 The integration of psychological dimensions in the economic analysis has been introduced at the beginning of the twentieth century, before being emphasized recently. An important unsolved question is whether psychological dimension has a proper effect on action that is different from the effects of what has produced this psychological dimension, like experience, knowledge, social connexions.

13 The concept of mental model is connected with a series of other concepts such as "beliefs" (Greif 1994; Weymouth \& Broz 2006), "psychology factors” (Henrekson \& Dreber, 2005), "values" (Scarritt, 2006), “ideas” (Zweynert, 2005), “culture” (Williams, 2005; Greif, 2006). This section aims to illustrate what mental models can add to these concepts.

14 The idea that "beliefs" could play a role in the economy goes back to Peirce (1877) and has been developed more recently by authors like Hayek, who sees beliefs as a spirit construct that permits agents to interpret their environment (Hayek 1952). In that sense it is very 
close to the concept of mental models as defined more recently by Denzau and North "the internal representations that individuals create to interpret the environment" (Denzau and North, 1994, p.2). The mental model tends to give a coherence to our believes. If in a negotiation between an elephant and a mouse, if the elephant believes that he is a lamb and that the mouse is a wolf, he takes the behaviour of a lamb in front a wolf. The lamb is a - caricatured - mental model. As most models, it is a "device" to give coherence to a complex thing. Mental model helps giving coherence to a bundle of believes. It is directly related to Durkheim's representations. The concept of representation also expresses the need to give coherence to a bundle of incoherent believes. It gives an image of oneself in an environment, and because all relevant information to produce this image is not available, this image is only an interpretation of the reality. If the two ideas are very similar, mental models have been developed in the new institutional economics context, probably in the ultimate intention to judge the economic efficiency of the mental models. Do mental model actually help people, and in what circumstances? Are there "better" mental model than others? This stands in line with the development by Aoki: "why there can be "good" as well as "bad" institutions in terms of their consequences to economic development and societal evolution" (Aoki, 2001).

Economic efficiency has always been the final point in North's efforts to understand how mental models affect strategic choices and institutional structures (Knight and North 1997, North 2005; Denzau and North, 1994). North further analyzes mental models' interaction with institutions: guiding actions, mental models shape institutions, and, at the end, the evolution of societies: "institutions are the external manifestation of that representation" (North, 2005, p.49). This concept is also similar to the concept of "model of the economy" as developed by Keynes. For Keynes also models guide agents' actions especially under uncertainty, and agents need to extract their models out of their experience and their observation of the world (Keynes 1978).

Both the Keynesian and the new institutional economics include a learning process for the mental model to fit the environment. People "learn the model of the model they use in making decisions" (Minsky 1996). This process gives mental models their dynamic feature, and makes them "unstable beliefs" (Runde 1991). Agents construct their own models according to their experiences and making reference to their cultural milieu: in such a learning process, the models are likely to be inadapted to the prevailing institutional environment, notably just after a change has occurred within this environment. In a situation of an external institutional change, agents may need time to integrate this change: their mental models may not adapt instantly and lead to inefficient behaviours (North 2005). Mantzanivos et al. (2003), develop this idea that mental structures are flexible and changing as knowledge evolves. The time needed for this learning process to happen may lead to situations of little consistence between agents' expectations and the economic events (Carabelli and De Vecchi 2010). This discrepancy can lead to a crisis of the beliefs framework when the gap between expected situation and actual situation exceeds people's adaptation capacity (Aoki, 2001).

The information imperfection is a critical aspect of mental models. If people are perfectly informed of their strengths and defaults and of their environment, they adopt an appropriate behaviour. The mental model helps them to act without perfect information. In that sense, mental models are also connected to the concepts of thinking habits, and to the concept of bounded rationality. The concepts of "habits of thought" (Veblen, 1914, p 53.; Veblen, 1919, p. 239), of "thinking habits" (Commons, 1935) were developed in the old 
institutional economics. These habits are analysed as a propensity or disposition to think in a repeated way that may guide agents' action. The habit also is seen as a potential device to help people taking decision in the dark, as mental model. The difference between mental models and habits of thoughts is that mental model does not include the idea of repetition, and habits do not include the idea of coherence. People can have hundreds of disconnected thinking habits, "one for each case". Nevertheless, for some authors, mental models are influenced by habits of thoughts, which all together, lead to a representation of the environment. For Hodgson, mental models result from habits of thoughts, defined in the old institutionalist tradition as what help agents to "perceive or make sense of the data received by their senses" (Hodgson, 1998, p 189).

18 As the concept of bounded rationality (Simon, 1957), the concept of mental models assumes that agents are limited by the information they have (their knowledge of their institutional environment in particular) and by their cognitive capacities (their interpretation of this institutional environment and, in a reflective way, of their place in that environment). Because of this interpretation, action cannot be predicted by people's economic interest, action follows a of subjective patterns, such as mental models.

ent mental model primarily refers to individuals. However, individual mental models are embedded in a social and institutional context (North, 2005, p.33), and are strongly affected by social interactions. Thus, in a given society, individual mental models tend to converge to create "shared mental models" (Denzau and North, 1994). Durkheim (1989) was probably a pioneer of the idea of collective representation, and the idea of shared mental models is inherited of this literature. A shared mental model when extended at the society level is also an element of the culture. When Greif explains how the culture of a society shapes its institution (Greif, 1994; Greif 2006), it is similar to how the mental model of an economic sector shapes its institutional environment. In a similar perspective, Hall (1989) analyses how a "ideas of a nation" or ideas of a government can have a fundamental impact on its policy, and the society's economy.

In our research on farm policy negotiations in Costa Rica, we consider that the organization is a unit in which farmers individual mental models are similar (i.e. existence of a shared mental model) and that in each organization, the leader's individual mental model is representative of the organization's shared mental model. Organizations' policy behaviours are determined by organizations' leaders, which are not necessarily representative of farmers in their organization (most likely leaders are chosen for their specific abilities to resist, adapt, or take part to institutional changes) but whose mental model includes a shared part of farmers' mental models.

\section{The need for more empirical evidence}

The search for empirical evidence of the very role of psychology in economy in addition to non -psychological factors is still not fully successful. Many authors from the new institutional economics underline the need to include mental models in particular into empirical economics as a way to improve the empirical "proofs" of above intuitions. A few studies explicitly deal with mental models in the field of management and help to imagine a methodological framework (Carley 1997, Hodgkinson 1997). Thus, there is no evidence that mental models determine behaviours and are not simply the cognitive counterpart of an economic position. There is no quantification of mental models contribution to explain choices, nor empirical description of their effect. "Mental 
models" is not a concept which most economists are comfortable with. To our understanding this has much to do with the methodological challenges raised by the issue. Since mental models are dynamics and result from people's history, how could they be at the same time determinant of people's action, how could they be more than a simple manifestation of people's changing resources, knowledge, and capacities? How could mental model be useful to understand action if we understand what has shaped these mental models? Mental models add coherence to independent pieces of experience, how does action need this coherence?

The relations between mental models and institutions still constitutes a research area that has to be explored in an empirical way, in order to better understand the mechanisms under action (Alston 1996; North 1997; Shirley 2004). In this paper, we aim to bring such pieces of evidence and describe how mental models influence strategic choices made by collective actors, drawing on the example of farm organizations in Costa Rica, and building upon an innovative methodological posture. Our objective is to test the hypothesis that mental models influence strategic behaviours which is something different than describing a set of events in the light of the mental models agents may have.

\section{Empirical characterization of mental models}

The principle underlying our method of mental model characterisation is that the words used by two different persons placed in a same situation may reveal differences in their mental model. We build upon a statistical analysis of textual data, i.e. discourses of farm organisations leaders for bean and dairy organizations. The data used in this paper were collected during extensive interviews carried out in 2006 with eleven organizations' leaders.

\section{Qualifying mental models through textual analysis}

The analysis is made with ALCESTE ${ }^{1}$ lexicometric software (Viaud, 2002). This software builds multivariate analyzes to discover similarities and distinctions between several texts and relate these properties to psychological elements of their authors. It has been developed in the 1980s, and relies on the hypothesis that the words used by actors reveal their subjacent mental representations of the world (Reinert, 1986, p.472). The statistical analysis of textual data provides:

- a quantitative definition of the lexical specificity of each text, based on the statistical identification of words that appear to be representative of this text (occurrence calculations, the quantitative test for a word to be representative of a class being a Chi-square statistics $\left.{ }^{2}\right)$

- a limited number of lexical classes based on inter-text representative words

- a structural information on classes (words co-occurrence calculations).

Since the texts are based on interviews about the negotiation, the words and words associations that appear specific of a class, reveal the way this person perceives the negotiation and his position in the negotiation. These words that are specific of a class are used to interpret this class in terms of a mental model. Once classes are identified and labelled in terms of mental models, we simply have to find out which organizations contribute to defining which classes, and we can then associate identified mental models 
with organisations. The statistics used for this stage is another Chi-square statistics, giving the absolute contribution of a whole text to a class. The relative contribution of this text to a class (as compared to its contribution to all classes) is the parameter we seek: the probability that a text contributes to a particular class, or, in other words, the probability that the author of this text has the mental model characteristics of this class.

This calculation is led as follows. A discourse from organization $i$ is fragmented into $j$ strings of words. The contribution of each string to each lexical class $k$ is given by a Chisquare, $\chi_{i, j, k^{\prime}}^{2}$. If this value is zero, this string does not contribute to class $k$ and if this value is strictly positive, the relative contribution of string $j$ to class $k$ is all the greater as $\chi_{i j ; k}^{2}$ is great. As a discourse is made of many strings that belong to different classes, a discourse is characterized by several (JK) Chi-squares of the above kind. The contribution of a text $i$ to a class $k$ is

$$
C_{i, k}=\sum_{j=1}^{J} \chi_{i, j, k}^{2}
$$

The global contribution of a text $i$ to all classes is simply the sum of above contributions:

$$
G C_{i}=\sum_{k=1}^{K} \sum_{j=1}^{J} \chi_{i, j, k}^{2}
$$

And the relative contribution of a text $i$ to a class $k$ is the ratio between the two expressions:

$$
\phi_{i, k}=\frac{C_{i, k}}{G C_{i}}
$$

$\Phi_{i, 12}$ close to 1 indicates that the leader's discourse belongs almost entirely to class 1 and class 2, and $\Phi_{\mathrm{i}, 12}$ close to zero indicates a weak contribution of the leader's discourse to class 1 and class 2 . 


\section{Leaders' representativeness}

31 We met eleven organization's leaders: three from the milk sector, four from the bean sector, and four from other farm sectors, to increase the lexical diversity and the robustness or our results. Interviews were carried out in an open way to avoid inducing vocabulary similarities. Leaders were asked the following question: "What do you think about the policy making processes ongoing in your sector?".

Among the seven leaders interviewed representing bean and dairy sectors, three were paid full-time for their advocacy activities and were based in San José, the country's capital. One leader, with a background in international trade, was representing and defending the interests of the dairy sector (producers and processors). This leader descended from a family of dairy farmers, even though he himself had never worked in milk production. Two leaders were representing the interests not only of the bean sector but of a whole range of small scale farmers. One leader had started in small scale food crop production and had been selected by farmers and local based farmers' organizations to lead a protest peasant movement at the national level. The other leader had a background in sociology and joined an alternative movement.

The remaining four leaders were representing organizations whose main activities are the processing and marketing of production. In the dairy sector, two leaders were paid by the organization they were representing. One of them was directly involved in milk production and served as manager of a small scale cooperative. The other one held the position of chief operation officer in a large scale dairy cooperative and was not issued from a dairy farmers family. In the bean sector, the two leaders interviewed were representing organizations without being paid for that: both drew their salary from farming.

This brief presentation aims to show that leaders are generally representative of the population whose interests they defend. Two of three leaders representing dairy organizations were issued from dairy farmers' families, and three of four leaders representing bean organizations came from small scale farmers' families involved in staple food production.

\section{Statistical results: two differentiated types of mental models}

Leaders' discourses have been fully translated from Spanish to French, transcribed and analyzed with ALCESTE software. The analysis is made on a total corpus of 10367 words, corresponding to a total number of 298 elementary context units ("ecu"), $64 \%$ of them being classified. The analysis provided four classes, presented in Table 2, those classes presenting a high internal homogeneity and a low external homogeneity. Classes are defined by representative words, those words having different weights in the constitution of the classes and being related to each other (see the ascending classification in the Annex). The figures into brackets correspond to the associated Chi-square: the higher the Chi-square, the higher the importance of the representative word in the constitution of the class. 
Table 2. Results of lexicometric analysis

\begin{tabular}{|l|l|l|l|l|}
\hline & Class 1 & Class2 & Class 4 & Class 3 \\
\hline Representative words & $\begin{array}{l}\text { Difficult- (14) } \\
\text { Differen- (8) } \\
\text { Tariff (8) }\end{array}$ & $\begin{array}{l}\text { Support (13) } \\
\text { Search (9) }\end{array}$ & $\begin{array}{l}\text { Sector (10) } \\
\text { Development (6) } \\
\text { Represent (6) } \\
\text { Relation (5) }\end{array}$ & $\begin{array}{l}\text { Take (24), } \\
\text { Minist- (18), } \\
\text { Econom- (17), } \\
\text { Agricult- (17), } \\
\text { Trade (31) } \\
\text { Fogotiat (25), } \\
\text { Go (17), } \\
\text { Decision (10) }\end{array}$ \\
\hline Sectors & Bean (20) & Bean (8) & Milk (58) & 25.2\% \\
\hline \% of classified ecu & $35.4 \%$ & $24.1 \%$ & 15.2\% \\
\hline
\end{tabular}

Four lexical classes were identified by the analysis. The dairy sector is highly represented by class 4 ( 58 chi-square), while bean sector is represented by class 1 ( 20 chi-square) and to a lower extend by class 2 ( 8 chi-square). This indicates that leaders' discourses are pretty homogenous in the dairy sector and are more heterogeneous in the bean sector. None of the sector variables is located in class 3: this class could be interpreted as a common field of perception of the policy negotiation process, meaning that generally speaking, leaders from both bean and dairy sectors are aware of the actions they have to carry out and of the right policy spaces they have to lobby at. The interpretation of the content of the three other lexicometric classes in terms of mental models is not straightforward. Although this interpretation is not necessary for the rest of our analysis, we can suggest a tentative interpretation.

Some representative words of classes 1 and 2 ("difficult", "support" could reveal a defensive or negative perception towards policy negotiation processes. In this class, some specific wods are compatible with a perception of the negotiation, where actors cannot influence it so much. . On the contrary, the representative words of class 4 ("represent", "relation") are compatible with a proactive perception of policy negotiation processes, where the negotiation is seen as a real opportunity to represent ones interests and to gain policy support. This can be related to higher expectations.

There seems to be a consistency between the way organizations actually participate to policy making (behaviour) and the way leaders perceive this process (mental model). In the dairy sector, leaders speak as if they were aware that their implication in the negotiation can have a real impact on the negotiation outcome: policy making is perceived as a real opportunity and the behaviour can be qualified as proactive ("policy maker"). They have experienced that the policy making process is a negotiation in which they have a bargaining power which involves resources, and not an exogenous political phenomenon. In the bean sector, the identified mental model tend to support the thesis that policy making is perceived as an exogenous mechanism which they cannot really influence, and the behaviour can be qualified as defensive ("policy taker"). 
The dynamics of institutional change can be faster than the dynamic of mental models. The mental model prevailing in the dairy sector seems consistent with the liberalization ongoing policy reforms. The mental model prevailing in the bean sector can appear as inconsistent within the liberalization context, but could be consistent with the preliberalization context. But if we look at the context before liberalization, it gives quite a different picture. Indeed, in the bean sector, the institutional environment was basically made of public support to farmers under the form of production subsidies: farmers were in position of "receiving" a stable public support without having to negotiate it. Their policy taker attitude was adapted to that specific context, which could explain a policy taker attitude in the first stages of the liberalization. In the milk sector, there were important public regulations too but professional organizations used to negotiate the regulations content, and were encouraged to do so. This past of strong and frequent interactions between milk sector and the government explains that mental model tends to indicate an active participation in policy making processes and efficient policy results.

\section{The model}

In this section, we present the general model used to attribute what part of the difference in negotiation outcomes is due to objective factors such as technical, human and financial resources, and what part is eventually due to mental models.

41 The purpose of our model is to better present and discuss to what extent the negotiator's mental model can be considered as an additional factor of the negotiation outcome, and not only as another interpretation of existing explanations. In other words, the model is meant to accept or reject the idea that if a negotiator from the bean sector had a mental model from the negotiator in the bean sector, but with his own negotiation skills, financial, human and technical resources, he would have achieved a different outcome. The model is meant to raise the question whether we are allowed to think ceteris paribus about mental model. Is it correct to imagine people with their skills but a different mental model, which would play a distinct role on their economic achievement? To be concrete, if the bean negotiators were born more demanding, or if the history of their social milieu, of their organisation had made them more ambitious, or more demanding, without improving their other capacities, they may have achieved higher political support. Conversely, if the negotiators in the milk sector were born less demanding, or had not learnt to demand a lot during their political life, they may have achieved a lower political support.

42 The idea that mental model is an additional factor of outcome more than a combination of existing factors can be represented as follows. If Mental model was a purely exogenous variable, for instance if people were born with a definite mental model, there would be no econometric problem in the assessment of their role in the outcome. But it is not the case. Mental models are partly determined by innate character of the individual (which we do not measure) and by the individual's evolution in a social milieu, including in his farm organisation. Because of this, mental models could be correlated with the outcome without being a cause of the outcome, but simply a result from the negotiation skills and resources, that would be the true cause of the outcome. We cannot technically demonstrate that this is not the case. But we can restrict our measure of the mental model to limit this possibility. We need to focus on the innate side of the psychological dimension of mental model more than on its intellectual dimension. The mental model 
we deal with relates to the propensity of someone to expect a lot or not from an uncertain process. In that sense, it is close to someone's ambition, which is different from his ability to achieve his goal.

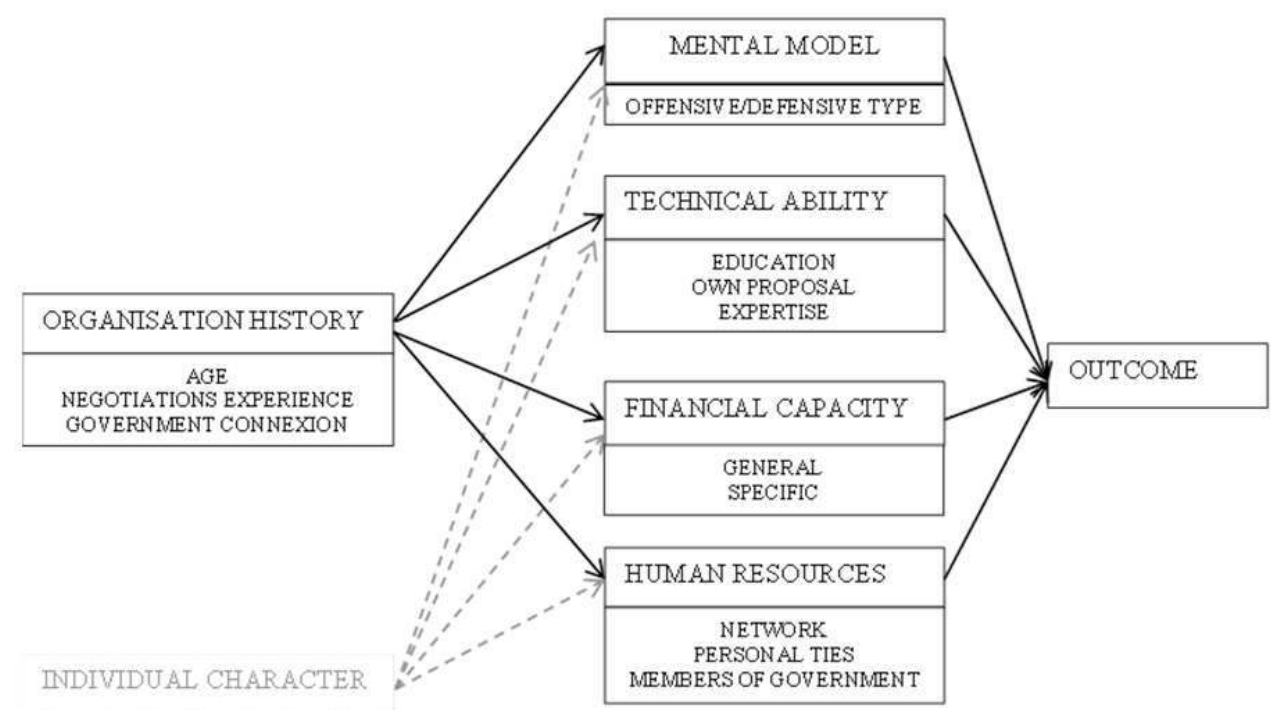

The negotiation outcome results from four factors that are not directly measurable or are multidimensional: mental model, technical ability, financial capacity and human resources. The outcome is the public support for the the farm sector that results from the negotiation. Mental model is supposed to be correlated to the fact that the leader sees the negotiation as a losing game (and his objective is to lose as little as possible) or a winning gam (and his objective is to win as much as possible). Technical ability depends on three measurable dimensions: the fact the leaders have a management degree or not, the fact that the organization has elaborated its own proposal for the negotiation, the fact that the organization has an expertise. The human resources also result in three factors: the insertion in policy network, its ties with politics, and the fact that some of her mebers belong to government. Financial resources depend on resources specifically dedicated to lobbying activity and financial resources in general.

These four factors themselves result from the organisation's history and their negotiator's Individual preferences, skills and other characteristics. The role of these individual characteristics on these four factors is not made explicit in our empirical estimation of the model. Only the role of the organization history is. This history has three dimensions: its age, its previous participations to negotiations, its previous interactions with policy makers.

\section{Empirical estimation}

Several methodological difficulties arise in the empirical estimation of such a model. Firstly, we have too few observations - eleven organisations - to make a least square 
estimation. We do not interview farmers, but their leaders who actually take part to the negotiation. Secondly, our four explanatory factors of the outcome are not purely exogenous variables, but combinations of variables that also potentially endogenous. For instance, the fact that an organisation is inserted in a network before the negotiation may well be a consequence of the negotiation to come and the expected outcome. It would then be a mistake to consider it as an explanation of a good outcome. For this reason as well a least square estimation is not consistent. The appropriate method for the kind of model we aim at estimating is typically a partial least square (PLS) modelling approach (Lohmöller, 1989; Wold, 1982, Tenenhaus, 1995). Our PLS model has two steps:

- We estimate the six latent (unobserved) variables out of the manifest (observed) variables. We measure the structural relationships between those six latent variables as drawn in figure 1. Signs and significance of the relationships between latent variables confirm or not the theoretical relationships that we have assumed. If we find that the mental model has no influence on the outcome, or that the mental model associated with the bean sector yields a better outcome ceteris paribus, that means that mental models play no role or a un unexpected role in the negotiation.

OUTCOME $_{i}=\beta_{0}+\beta_{2} \cdot$ MENTAL_MODEL $_{i}+\beta_{3} \cdot$ TECHNICS $_{i}+\beta_{4} \cdot$ HUMAN $_{i}+\beta_{5} \cdot$ FINANCE $_{i}+v_{i}$

48 - In a first step, each latent variable is estimated as a linear combination of its observable variables (Tenenhaus et al., 2005, p. 167). In a second step, the causal model is estimated trough a partial least square estimation of the following structural equations:

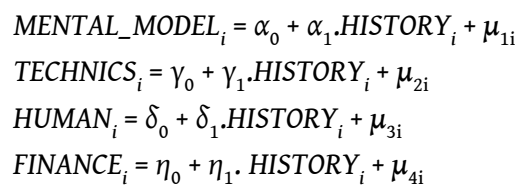

Organisation's history is summarized by the latent variable HISTORY, a linear combination of three manifest variables: AGE is the organisation age, EXPERIENCE is a dummy variable ( 1 if the organisation had participated at least to one policy negotiation before this one, zero if not), INTERACTION is a dummy variable ( 1 if the organisation had had interaction with policy makers before, zero if not).

50 Mental model is a latent variable that is a function of one observable variable only, which is our measurement of mental model. This measure is presented below in a specific section. When MENTAL_MODEL is close to 1 , it means that the leader has very low expectations regarding the policy negotiation, while when MENTAL_MODEL is closed to 0 , it means that the leader has high expectations and is mentally prepared to a winning game. A lexical analysis of leaders' discourses establishes several mental types, and MENTAL_MODEL is the probability to belong to the type corresponding to low expectations. The practical measurement of this probability is detailed in section 3.

51 Technical ability is a latent variable (TECHNICS) depending on three observable variables: the percentage of leaders in the organisation's management team with a university degree (EDUCATION), a dummy variable for the case whether the organisation has made up its own proposal for the negotiation (PROPOSAL), and a dummy variable whether the organisation has been solicitude for her expertise (EXPERTISE).

Human resource is a latent variable (HUMAN) depending on three observable variables: The insertion in formal policy network (NETWORK), the existence of personal ties with policy makers (TIES), the fact that the organisation is member of the government or not (GOVERNMENT). 

how much mioney is spent specifically on policy making activity (SPECIFIC) and wherther or not the total amount of financial resource in the organisation is greater than the national average (GLOBAL).

OUTCOME is the latent value for negotiation outcome, resulting from one observable variable: the degree of economic protection, evaluated in terms of the main policy measure under discussion, i.e. the tariff level. A higher level of policy measure $\delta$ is synonymous of better result for the organization. At the end of the negotiation, the negotiated policy measure $\delta^{*}$ is a weighted average of the ideal policy level $\delta^{i}$ achievable by organization and the policy level proposed by the other party (government under pressure of other WTO third countries $) \delta$.

$$
\delta^{*}=\alpha . \delta^{i}+(1-\alpha) \delta
$$

support is high, meaning a positive outcome. A value close to zero reveals a low protection, or a low negotiation outcome. We find $\alpha$ to be a good indicator of the outcome, so that we set

$$
\text { OUTCOME }=\alpha=\frac{\delta^{*}-\bar{\delta}}{\delta^{i}-\overline{\delta_{i}}}
$$

\section{Results: Mental models role in behaviours}

\section{Empirical estimation of the model}

The table 4 presents the estimation of the 6 latent variables from the 13 manifest variables. The stability of the result is tested following test by Chin (1998) and Hulland, (1999), and the six latent variables are stable. Individual item reliability is considered as adequate when its factor loading is greater than 0,7 ; the fit between a latent variable and its manifest variables is good when the latent variable composite reliability is greater than 0,8 and its average variance extracted is greater than 0,5 . As in an ordinary least square regression, a t-stat greater than 1,96 indicates that the relationship between a manifest variable and the latent is significant at the $5 \%$ level. Table 3 synthesizes results on the estimation of the six latent variables. 
Table 3. Estimation of the six latent variables of our model

\begin{tabular}{|c|c|c|c|c|c|c|c|}
\hline Latent variable & $\begin{array}{l}\text { Composit } \\
\text { e } \\
\text { reliability }\end{array}$ & $\begin{array}{l}\text { Average } \\
\text { variance } \\
\text { extracte } \\
\text { d }\end{array}$ & $\begin{array}{l}\text { Manifest } \\
\text { variables }\end{array}$ & $\begin{array}{l}\text { Weigh } \\
\mathrm{t}\end{array}$ & $\begin{array}{l}\text { Loadin } \\
\mathrm{g}\end{array}$ & $\begin{array}{l}\text { Standar } \\
\text { d error }\end{array}$ & $\begin{array}{l}\text { t- } \\
\text { stat }\end{array}$ \\
\hline \multirow[t]{3}{*}{ HISTORY } & 0,90 & 0,75 & Age & - & - & - & - \\
\hline & & & Experience & 0,28 & 0,83 & 0,04 & 18,3 \\
\hline & & & $\begin{array}{l}\text { Interaction } \\
\mathrm{s}\end{array}$ & 0,39 & 0,91 & 0,13 & $\begin{array}{l}8 \\
6,73\end{array}$ \\
\hline \multirow[t]{3}{*}{$\begin{array}{l}\text { MENTAL_MOD } \\
E L\end{array}$} & 1 & 1 & $\phi_{1,2}$ & 1 & 1 & - & - \\
\hline & & & $\begin{array}{l}\text { Probability } \\
\text { to belong }\end{array}$ & & & & \\
\hline & & & $\begin{array}{l}\text { to class } 1 \\
\text { or } 2\end{array}$ & & & & \\
\hline \multirow[t]{3}{*}{ TECNICS } & 0,88 & 0,71 & Education & 0,41 & 0,87 & 0,18 & 4,88 \\
\hline & & & Proposal & 0,45 & 0,92 & 0,23 & 4,04 \\
\hline & & & Expertise & 0,33 & 0,71 & 0,28 & 2,52 \\
\hline \multirow[t]{4}{*}{$H U M A N$} & 0,78 & 0,50 & Network & 0,62 & 0,83 & 0,21 & 3,89 \\
\hline & & & Governme & 0,56 & 0,79 & 0,07 & 10,2 \\
\hline & & & $n t$ & - & - & - & 4 \\
\hline & & & Ties & & & & - \\
\hline \multirow[t]{2}{*}{ FINANCE } & 0,95 & 0,90 & Specific & 0,57 & 0,96 & 0,06 & 15,1 \\
\hline & & & Global & 0,48 & 0,94 & 0,13 & $\begin{array}{l}1 \\
7,35 \\
\end{array}$ \\
\hline OUTCOME & 1 & 1 & $\begin{array}{l}\alpha \\
\text { protection } \\
\text { level }\end{array}$ & 1 & 1 & - & - \\
\hline
\end{tabular}

Table 4 presents the relationships between the six constructed latent variables of our structural model.

Table 4. Estimation of the structural model

\begin{tabular}{|c|c|c|c|c|c|}
\hline $\begin{array}{l}\text { Dependent } \\
\text { variable }\end{array}$ & $\begin{array}{l}\text { Independent } \\
\text { variable }\end{array}$ & Coefficient & $\begin{array}{l}\text { Standard } \\
\text { deviation }\end{array}$ & $\begin{array}{l}\text { Upper } \\
\text { limit } \\
(95 \%)\end{array}$ & $\begin{array}{l}\text { Lower } \\
\text { limit } \\
(95 \%)\end{array}$ \\
\hline MENTAL_MODEL & HISTORY & $-0,932$ & 0,048 & $-1,026$ & $-0,838$ \\
\hline TECHNICS & HISTORY & 0,923 & 0,070 & 0,787 & 1,060 \\
\hline$H U M A N$ & HISTORY & 0,902 & 0,094 & 0,717 & 1,086 \\
\hline FINANCE & HISTORY & 0,865 & 0,058 & 0,750 & 0,979 \\
\hline \multirow[t]{4}{*}{ OUTCOME } & MENTAL_MODEL & $-0,260$ & 0,024 & $-0,308$ & $-0,212$ \\
\hline & TECHNICS & 0,264 & 0,019 & 0,226 & 0,302 \\
\hline & $H U M A N$ & 0,258 & 0,019 & 0,220 & 0,296 \\
\hline & FINANCE & 0,239 & 0,012 & 0,216 & 0,262 \\
\hline
\end{tabular}

The four first rows in table 4 simply indicate how experience in negotiation influences the different factors explaining negotiation outcome. Their role in our analysis is only to show that neither mental models nor the organisation skills and resources are purely 
exogenous. They evolve with time and with experience. The results confirm that having a significant experience in policy negotiation processes decreases the probability to coin a mental model from class 1 and 2 (the "defensive" type), $\beta=-0,932$. This experience, tends to increase technical abilities, human resources, and financial resources, as defined by our manifest variables.

The four last rows indicate how these latent variables explain the outcome. As expected, technical, human and financial resources influence positively the negotiation outcome, which has already been confirmed by a vast literature (Penrose 1959, Mac Carthy and Zald 1977, Wernerfelt 1984, Barney 1997). We also show that mental models have a significant weight on the policy outcomes obtained $(\beta=-0,260)$, which means the mental model of a defensive type decreases the chance to get a better outcome from the negotiation. Although once could consider this as an obvious statement, the impact of mental model on an economic outcome had not been measured yet. Furthermore, the relative weight of mental models in the determination of policy outcomes is quite equivalent to the relative weight of technical abilities and human resources and slightly higher in absolute value to the weight of financial capacities in the constitution of the outcomes. The way policy negotiations are perceived by organizations' leaders is directly influencing the policy outcomes obtained.

\section{Discussion}

Our results suggest that negotiators in the sector have too low expectations toward the ongoing negotiation about mitigating policies during the liberalisation process. Their mental model does not seem adapted to the negotiation. This does not reveal a lack of interest to take part to the change, but more likely a lack of auto-legitimation to take part to the change.

61 The pre-liberalisation environment had favoured a "policy-taking" attitude in the bean sector, because most farmers in the bean sector have little investment, little profit, and little economic risk. They are not used to be helped, nor threatened. They cannot run bankrupt and cannot easily become rich. This does not favour mentalities which claim any policy support from anyone, even though the aggregate economic stakes of liberalisation may be as great as in the milk sector. In order to be a good negotiator, you have to claim, and you have to be convinced that you have a right to get economic support. In the dairy sector, the institutional environment prevailing before the liberalization included incentives for farmers to take part actively to policy processes, but also to claim lower interest rates with banks, higher prices to buyers, etc. It is not clear whether farmer in the milk sector deserve a political support more than farmers in the bean sector, but they believe they do, and this make the difference.

Alternative interpretation could also be put forward to explain the lower outcome in the bean sector. In particular, the economic loss per farmer would probably be greater in the milk sector if liberalisation was complete and uncompensated, because of the economic investment in the milk sector. 


\section{Conclusion}

63 The starting point of this paper is the observation that, in the process of economic liberalization, some farm sectors in Costa Rica manage to negotiate a high import tariff whereas others do not, which has a tremendous consequences on farmers' life in the respective farm sector. . We make the hypothesis that some of the reason of these differences in attitude is a differences in their mental models, the defensive type being convinced that it is not legitimate for him to ask for policy support, the offensive type being convinced that it is legitimate for him to ask for support. We characterized the negotiators' mental models through a statistical analysis of their discourses and we measure the relative weight of mental models in the determination of policy outcomes obtained by organizations through a partial least square analysis. The main result is that mental models as we characterize them influence negotiations outcomes in the same proportion as financial resources, human resources or technical skills. The scope of what organizations' leaders consider to be legitimate expectations seems to have a significant impact on policy negotiation outcomes.

Mental models are shaped by specific institutional environments and adapt slowly to changes in those environments. When an exogenous change occurs, mental models tend to persist and may lead to inappropriate behaviours. We find that those organizations that have been used to negotiate have learnt to defend higher expectations, involve more resources in the negotiation, and tend to get more and quicker policy support in response to an economical change.

\section{BIBLIOGRAPHIE}

Alston, L., (1996). “Empirical work in institutional economics: an overview”. In Alston, Eggertsson and North, eds., Empirical Studies in Institutional Change, Cambridge, Cambridge University Press. Anderson, K., Hayami, Y., (1986). The political economy of agricultural protection. Sydney, Allen and Unwin.

Aoki M. 2001. Toward a Comparative Institutional Analysis, Massachusetts Institute of Technology Press, Cambridge.

Bowles, S., (2004). Microeconomics: behaviour, institutions and evolution, Princeton, Princeton University Press.

Carabelli, A., De Vecchi, N. (2001), "Hayek and Keynes: From a common critique of economic method to different theories of expectations", Review of Political Economy, Vol 13 (3), pp 269-285.

Carley, K., (1997). "Extracting team mental models through textual analysis”. Journal of Organizational Behaviour, 18(1), 533-558.

Chin, W. (1998). The partial least square approach for structural equation modeling. London: Laurence Erlbaum Associates. 
Commons, J., (1935). “The place of economics in social philosophy”. Journal of Social Philosophy. 1, 7-22.

Denzau, A., North, D., (1994). "Shared mental models: ideologies and institutions". Kyklos. 47, 3-30.

Émile Durkheim. (1898), Représentations individuelles et représentations collectives [archive], Revue de métaphysique et de morale, VI, p. 273-302

Greif, A., (1994). "Cultural beliefs and the organization of society: a historical and theoretical reflexion on collectivist and individualist societies", Journal of Political Economy. 102, 912-950.

Greif A., (2006) Institutions and the path to the modern economy: lessons from medieval trade, Cambridge University Press.

Hall P., (1989), The political power of economic ideas. Keynesianism across nations. Princeton University press.

Grindle, M., (2001). "In quest of the political : the political economy of development policy making”. In Meier and Stiglitz, eds., Frontiers of development economics: the future in perspective. Washington and New York, World Bank and Oxford University Press.

Hayek, F., (1952). The sensory order: an inquiry into the foundations of theoretical psychology. Chicago, University of Chicago Press.

Henrekson, M., Dreber, A., (2005). "Female Career Success: Institutions, Path Dependence and Psychology”. Paper presented at the ISNIE 2005 annual conference, Barcelona.

Hodgson, G., (1998) “The approach of institutional economics”, Journal of Economic Literature, 31(1) 166-192.

Hulland, J. (1999), "Use of Partial Least Square in strategic management research : a review of four recent studies", Strategic Management Journal, 20, 195-204.

Keynes, J.M, (1978 ed), The General Theory: Volume VII of The Collected Writings of John Maynard Keynes, Cambridge, Cambridge University Press.

Knight, J., North, D., (1997), “Explaining the complexity of institutional change”, In Weimer, ed., The political economy of property rights, Cambridge, Cambridge University Press.

Lohmöller, J., (1989). Latent variable path modelling with partial least squares, New York: Springer.

MacCarthy, J. Zald, M., (1977), "Resource mobilization and social movements: a partial theory", American Journal of Sociology. 82, n6, 1212-1241.

Mantzavinos C., North D. C., Shariq, S. 2003. « Learning, Institutions and Economic Performance ». Max Planck Institute for Research on Collective Goods, Bonn, pp. 1-19.

Ménard, C., (2007). “Cooperatives: Hierarchies or Hybrids?” In K. a. Nilsson (Ed.), Vertical Markets and Cooperative Hierarchies: The Role of Cooperatives in the Agri-Food Industry (pp. 1-17). New York: Springer.

Minsky H.P. (1996), “Uncertainty and the Institutional Structure of Capitalist Economies: Remarks upon Receiving the Veblen-Commons Award", Journal of Economic Issues, Vol. 30 (2), pp. 357-368.

North, D., (1990), Institutions, institutional change and economic performance, Cambridge, Cambridge University Press.

North, D., (1997). “The frontiers of the new institutional economics: prologue”, In Drobak and Nye, eds., The frontiers of the new institutional economics, San Diego, Academic Press. 
North, D., (2005), Understanding the process of economic change, Princeton and Oxford, Princeton University Press.

Peirce, C., (1977). “The fixation of belief”, Popular Science Monthly. 12, 1-15.

Penrose, E., (1959). The theory of growth of the firm, Oxford, Basil Blackwell.

Reinert, M., (1986). “Un logiciel d'analyse lexicale : Alceste », Les Cahiers de l'Analyse des Données. $11, \mathrm{n}^{\circ} 4,471-484$.

Rodrik, D., (1996), “Understanding Economic Policy Reform”, Journal of Economic Literature, 34, n $1,9-41$.

Runde J. (1991), "Keynesian uncertainty and the instability of beliefs", Review of Political Economy, Vol 3(2), pp 125-145

Scarritt, J., (2006), "Systems, Institutions and Strategic Choices in the Explanation of Economic, Political and Social Change and Continuity", Paper presented at the ISNIE 2006 annual conference, Boulder.

Simon, H., (1957). Models of man, New York, Wiley.

Veblen, T., (1914), The instinct of workmanship, and the state of the industrial arts, New York, Augustus Kelley.

Veblen, T., (1919), The place of science in modern civilization, New York, Viking Press.

Viaud, J., (2002), "Multidimensional analysis of textual data using Alceste and the social representation of unemployment", European Review of Applied Psychology, 52, n³, 201-212.

Wernerfelt, B., (1984), “A resource-based view of the firm”, Strategic Management Journal, 5, n¹, 171-180.

Weymouth, S., Broz, L., (2006), "Institutions and the credibility of government promises: Evidence from survey data", Paper presented at the ISNIE Conference, Boulder, USA.

Williams, L., (2005), “Culture Shock and Economic Outcomes”, Paper presented at the ISNIE 2005 annual conference, Barcelona.

Williamson, O. (1996), The mechanisms of governance, Oxford: Oxford University Press.

Wold, H., (1982), “Soft modelling: the basic design and some extensions", In Jöreskog \& Wold (Eds.), Systems under indirect observation: causality, structure, prediction, Amsterdam: North Holland Publishing Co.

Zweynert, J., (2005), “Economic Ideas and Institutional Change: Evidence from Soviet Economic Discourse 1987-1991" (Discussion Paper 324). Hamburg: Hamburg Institute of International Economic.

\section{NOTES}

1. From French, meaning "Analysis of Co-occurring Lexemes in Simple Utterances of a Written Text"

2. This Chi-square statistics for the definition of one class by one word is the contribution of this word to the identification of this class and refers to the probability to consider this word as representative of this class when it is not. Chi-square greater than 3,84 , means that there is less than $5 \%$ chance that this word is not representative of this class (in our case there is one degree of freedom). 


\section{RÉSUMÉS}

L'économie néo-institutionnelle a développé le concept de modèles mentaux, défini comme la façon dont les agents perçoivent leur environnement, pour analyser les comportements stratégiques. Cependant, peu de travaux portent explicitement sur la démonstration empirique de l'influence des modèles mentaux. Cet article analyse le rôle que jouent les modèles mentaux des leaders paysans dans les processus de négociation de politiques agricoles pendant le contexte de la libéralisation économique au Costa Rica. Les modèles mentaux sont caractérisés par une analyse statistique textuelle des discours des leaders. Le poids des modèles mentaux dans les négociations est ensuite analysé, relativement à d'autres facteurs explicatifs, par l'approche des moindres carrés ordinaires. Le principal résultat est que les modèles mentaux influencent l'issue des négociations, avec un poids comparable à celui des ressources financières, techniques et humaines.

The new institutional economics has recently developed the concept of mental model, defined as the way agents perceive their position in their environment, to analyze agents' behaviours. Nevertheless, the empirical evidence that mental models contribute to explain behaviors has not been made explicit. In this paper, we analyze the role of farm organisation leaders' mental model in a policy negotiation process, in a context of liberalisation in Costa Rica. We characterize mental models through a statistical textual analysis of leaders' discourses, and we measure mental models' relative weight in the negotiation outcome, building upon a partial least square approach. We find that mental models influence organizations' behaviours and outcomes, with a similar level of reliability than the organisation's financial resource, technical capacity, and human resource.

\section{INDEX}

Mots-clés : modèles mentaux, négociation, politiques

Keywords : mental models, negotiation, policies

Code JEL B15 - Historical • Institutional • Evolutionary, B25 - Historical • Institutional • Evolutionary • Austrian, B52 - Institutional • Evolutionary, Q18 - Agricultural Policy • Food Policy

\section{AUTEURS}

\section{ELODIE MAÎTRE D'HÔTEL}

CIRAD

\section{TRISTAN LE COTTY}

CIRAD 